\title{
Cultos africanistas e o uso do meio ambiente e do espaço urbano da cidade de Porto Alegre, RS
}

\begin{abstract}
Africanist cults and the use of the environment and urban space of the city of Porto
\end{abstract}
Alegre, RS

\section{Vladimir Stolzenberg Torres'}

\section{RESUMO}

A constituição federal brasileira relaciona dentre as garantias do cidadão o direito ao meio ambiente sadio e a liberdade religiosa e de liturgia. Também prevê como valor constitucional a ser defendido pelo Estado brasileiro as matrizes culturais africanas. A problemática da presente pesquisa é o conflito entre esses valores e garantias em um Estado democrático de direito, conflito este que identificamos no caso selecionado para estudo: praças da Intercap, bairro Partenon em Porto Alegre - RS. Assim, o objetivo da presente pesquisa é promover uma discussão deste conflito, de modo que esta contribua para uma solução válida e exeqüível em qualquer área verde sob administração pública. Evidencia-se que as normas protetivas do direito à liberdade religiosa têm eficácia absoluta, não podendo ser restringidas, através de Emendas ou com a elaboração de leis infraconstitucionais.

Palavras-chave: Liberdade de culto; Direito ambiente sustentável; Conflito Religião e Meio Ambiente

\section{ABSTRACT}

Brazilian federal constitution lists among the citizens guarantees not only the right to a healthy environment but also religious and liturgy freedom. It is also established as a constitutional value the State's obligation to preserve the cultural African matrixes. The main matter of the present research is the conflict between (or among) such guarantees and interests within a democratic system, as it has been identified in the study-case: Intercap squares, Partenon neighborhood in Porto Alegre - RS. It is evident that the protective norms of the right to religious freedom have absolute effectiveness and can not be restricted through Amendments or the elaboration of infraconstitutional laws.

\section{Keywords: Freedom of worship; Sustainable environment law; Conflict Religion and Environment}

\section{INTRODUÇÃO}

Levando-se em conta os diversos aspectos que, ao longo dos tempos, envolvem as praças, como definição, funções, usos e concepções, evidencia-se que 'Mestrado em Biociências pela PUCRS. Doutorado em Informática na Educação pela Universidade Federal do Rio Grande do Sul. Pósdoutorando em Arquitetura e Urbanismo. Especialista do CRBio-3, Técnico Científico - Superior - da Secretaria Municipal de Meio Ambiente de Porto Alegre. E-mail: vladimir@gmail.com ORCID: http://orcid.org/0000-0002-5027-7775 
tenham sofrido significativas mudanças. Todavia, é consensual que, a despeito das transformações decorridas, às praças ainda representam um espaço público de grande importância no cotidiano urbano (DE-ANGELIS et al., 2005). Como característica geral, então, as praças podem ser definidas, de maneira ampla, como qualquer espaço público urbano, livre de edificações que propicie convivência e/ou recreação para os seus usuários.

No âmbito deste estudo, comportam-se para análise os valores estéticos e simbólicos representantes da função das praças enquanto objetos referenciais e cênicos da paisagem urbana, além de exercer um importante papel na identidade de um bairro ou via pública. Assim, geralmente vinculado à concepção histórico-cultural, as praças são percebidas como espaço de diálogo, local acolhedor para o passeio e lazer de toda sociedade. Desta forma, do ponto de vista estético, as praças contribuem através das qualidades plásticas de cada uma das partes visíveis que as integram.

As religiões afrobrasileiras, conforme Silva (2013), ressignificam os lugares e, portanto, o sentido das representações sobre os espaços construídos, tal como estradas, encruzilhadas e espaços naturais, que possuem significados simbólicos.

A religiosidade africana tem sua origem em elementos da natureza, com os Orixás representando tais contextos, como Oxum nas águas correntes calmas, Obá nas águas correntes turbulentas, Iroko a mais antiga das árvores e assim sucessivamente. Para Silva (2013), dentro da cidade, os adeptos das religiões afrobrasileiras são agentes de configuração de outras territorialidades e comportamentos, sendo assim, é preciso reconhecer as diferentes temporalidades das culturas contidas na cidade.

A religião tem por base a "anima" (alma) da natureza, sendo, portanto, chamada de anímica, tendo sido desenvolvida no país com o conhecimento dos sacerdotes africanos que foram escravizados e trazidos da África para o Brasil, juntamente com seus orixás/inquices/voduns (o nome varia dependendo da etnia/nação), sua cultura e língua, especialmente no período entre 1549 e 1888 (COSTA, 2008).

De forma geral, a religião é uma variável pertinente na estruturação das relações sociais, é um sistema simbólico reunido em torno da experiência do 
concreto, não apenas na dimensão da totalidade social, como também na dimensão de cada e qualquer indivíduo (GIL-FILHO, 2008).

Ainda segundo Costa (2008), os escravos que vieram para o Brasil pertenciam a diversos grupos étnicos, incluindo os Yoruba, os Ewe, os Fon, e os Bantu. Como a religião ligada aos negros se tornou semi-independente na sua estratégia de resistência cultural em regiões diferentes do país, e entre grupos étnicos diferentes, evoluíram diversas "divisões" ou nações, que se distinguem entre si principalmente pelo conjunto de divindades veneradas, o toque do atabaque, os cânticos e a língua sagrada usada nos rituais. Assim, ao transposta para o Brasil, especialmente no âmbito do batuque riograndense se visualiza a perda da unidade original, se expressando como uma interessante amálgama de religiões, originalmente africanas (diversas vertentes, ou bacias, como o Nagô, a Cambinda, e a Jêje dentre outras) acrescidas de significados católicos e mesmo espíritas, e se constituindo, apesar de suas raízes, em todo um rico conjunto cultural em território brasileiro.

Porém, conforme Silva (2013), para interpretar o mundo através do sistema simbólico da religião é necessário fazer a diferenciação entre o nível material do espaço e o seu nível simbólico.

Assim, com práticas que resgatam segmentos marginais na sociedade moderna, essa religiosidade é importante na constituição identitária devido à forte concentração de praticantes que, através do seu culto aos orixás, podem ser elementos ativos no desenvolvimento e implantação de uma política pública focada na gestão ambiental. Sendo assim, o presente estudo realiza uma análise da dialética entre as garantias do cidadão ao direito a um meio ambiente sadio e a liberdade religiosa e de liturgia objetivando contribuir para a solução exitosa deste conflito, de modo que esta solução seja válida e exeqüível em qualquer área verde sob administração pública.

\section{MATERIAL E MÉTODOS}

O bairro Partenon foi criado pela Lei 2022 de 7/12/59, com limites ampliados no sentido leste, pela Lei 6572 de 08/01/90. Apresenta como uma de suas marcas, grandes contrastes em termos residenciais, talvez em função de sua grande área, que 
perfaz 470ha. Observa-se nele diferenças marcantes, como por exemplo, caracterizam as áreas da Intercap e a vila Maria da Conceição: a primeira possui belas praças, amplas ruas pavimentadas e arborizadas, com residências bem distribuídas no espaço e, em sua grande maioria, construídas em alvenaria, e a Conceição, possui casas distribuídas de acordo com as possibilidades do morro, geralmente construídas em madeira e com estrutura precária.

A Intercap é delimitada pelas avenidas Ipiranga, Antônio de Carvalho, Bento Gonçalves e Rua Albion (fig. 1), tendo sido eleita para o estudo por se tratar da microregião do bairro, onde ocorre a maior parte dos conflitos por uso das praças para o acolhimento de oferendas.

O estudo foi levado a cabo através da observação in loco nas praças da região, bem como, através dos registros constantes no sistema Fala Porto Alegre, que acolhe demandas da população pelo número 156, disponível todos os dias da semana nas 24 horas.

Figura 1. Intercap no bairro Partenon e sua delimitação pelas avenidas Ipiranga, Antônio de Carvalho, Bento Gonçalves e Rua Albion. A. Praça Darci Azambuja; B. Praça Leda Schnneider; e C. Praça Clio Fiori Druck (Modificado do Google Maps - Street View).

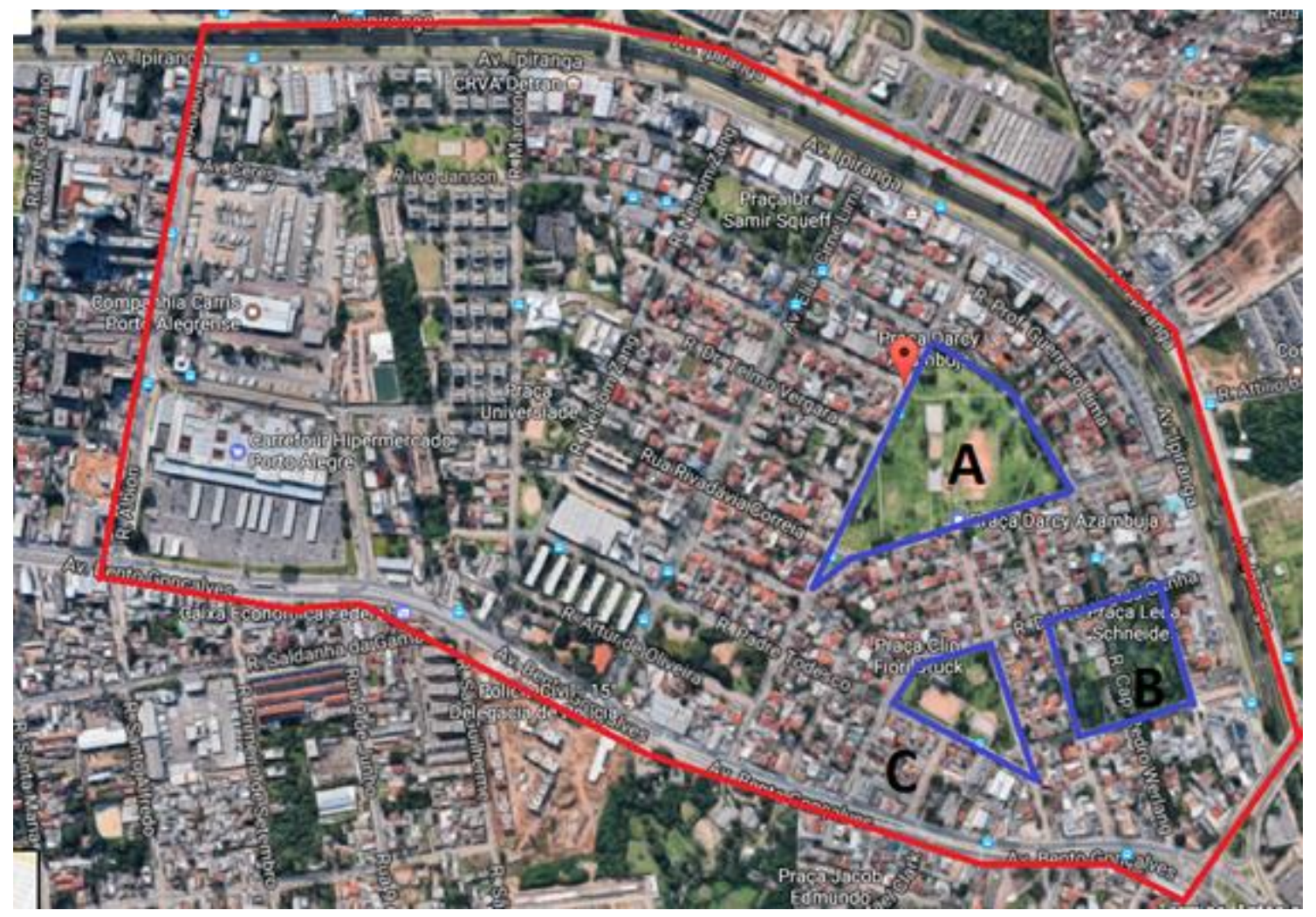


Foram objeto de estudo, neste momento, especialmente as Praças Darci Azambuja (figs. 1 e 2), totalizando uma área de $39.550 \mathrm{~m}^{2}$, Clio Fiori Druck (fig. 1) compreendendo $13.750 \mathrm{~m}^{2}$ e a Leda Schnneider (fig. 1) com 9.447m²; muito embora existam outras praças na região - Universíade, Dr. Samir Squeff, Tristão Sucupira Vianna, e Cel. Tristão José de Fraga.

Não foram considerados dados quantitativos, apenas qualitativos na busca de identificar a presença da intervenção religiosa no espaço público e a influência decorrente da mesma.

\section{RESULTADOS E DISCUSSÃO}

Para Silva (2013), as religiões afrobrasileiras, com seus adeptos, suas manifestações religiosas e seus locais de liturgias, de uma forma, ou de outra, também produzem e reproduzem o espaço. A temática da intolerância religiosa no Brasil não se constitui em uma novidade, trazendo discussões para além da questão sagrada, traz a complexidade das relações e interações sociais, como a xenofobia, a homofobia, o racismo, a discriminação com a população negra e com adeptos das religiões afro-brasileiras (SILVA, 2013).

Figura 2 - Comprometimento do colo de um exemplar de Peltophorum dubium (Spreng.) Taub. na Praça Darcy Azambuja (Acervo particular do autor).

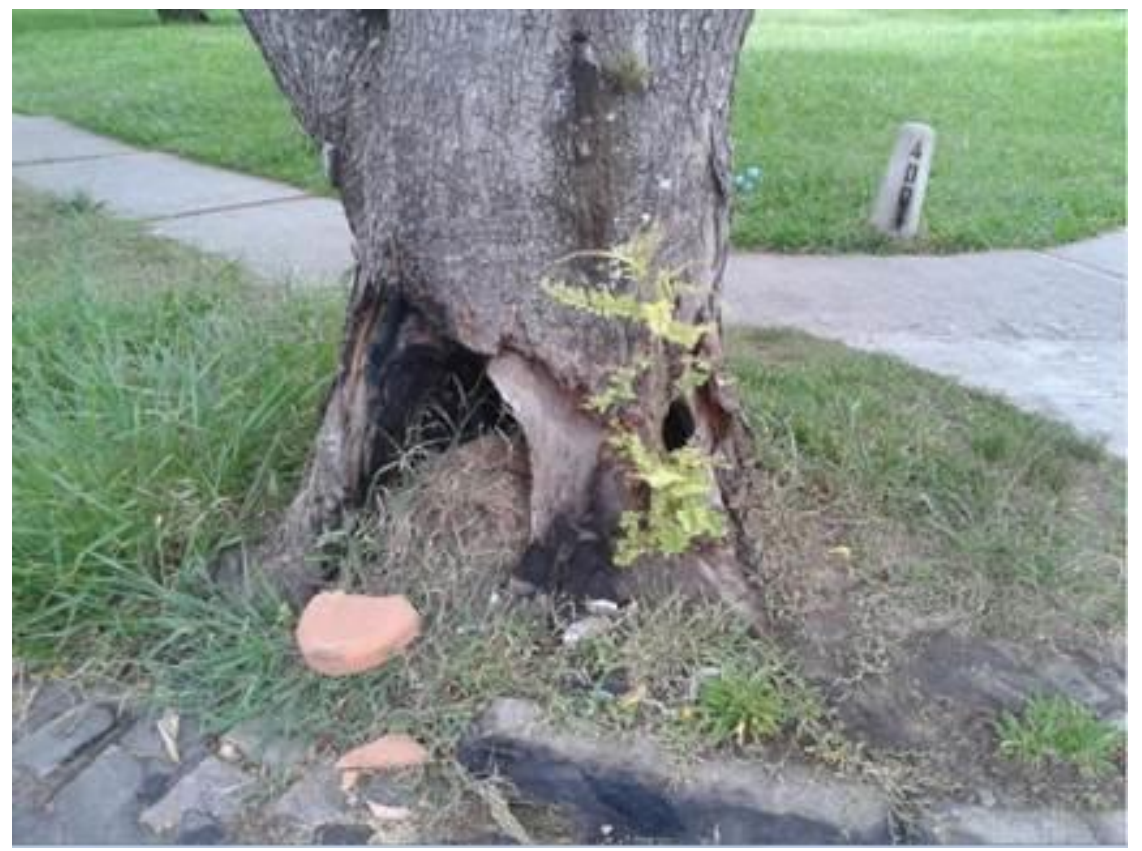


O conflito observado, no âmbito das praças da Intercap, decorre da entrega de oferendas nestes locais, com múltiplas situações, conforme se destacam: entrega junto ao colo das árvores, com isto ocasionando lesões ao fuste pelo fogo das velas (figs. 2 e 3), junto a monumentos, também com danos aos mesmos. Complementar, tem-se ainda, como possível conseqüência, a geração de resíduos religiosos (expressão cunhada pelo Decálogo das Oferendas, citado por Costa, 2008) - fig. 4.

Figura 3 - Comprometimento do colo de um exemplar de Tipuana tipu (Benth.) Kuntze, tendo sido realizada uma antiga dendrocirurgia ineficiente. Exemplar da Praça Leda Schnneider (Acervo particular do autor).

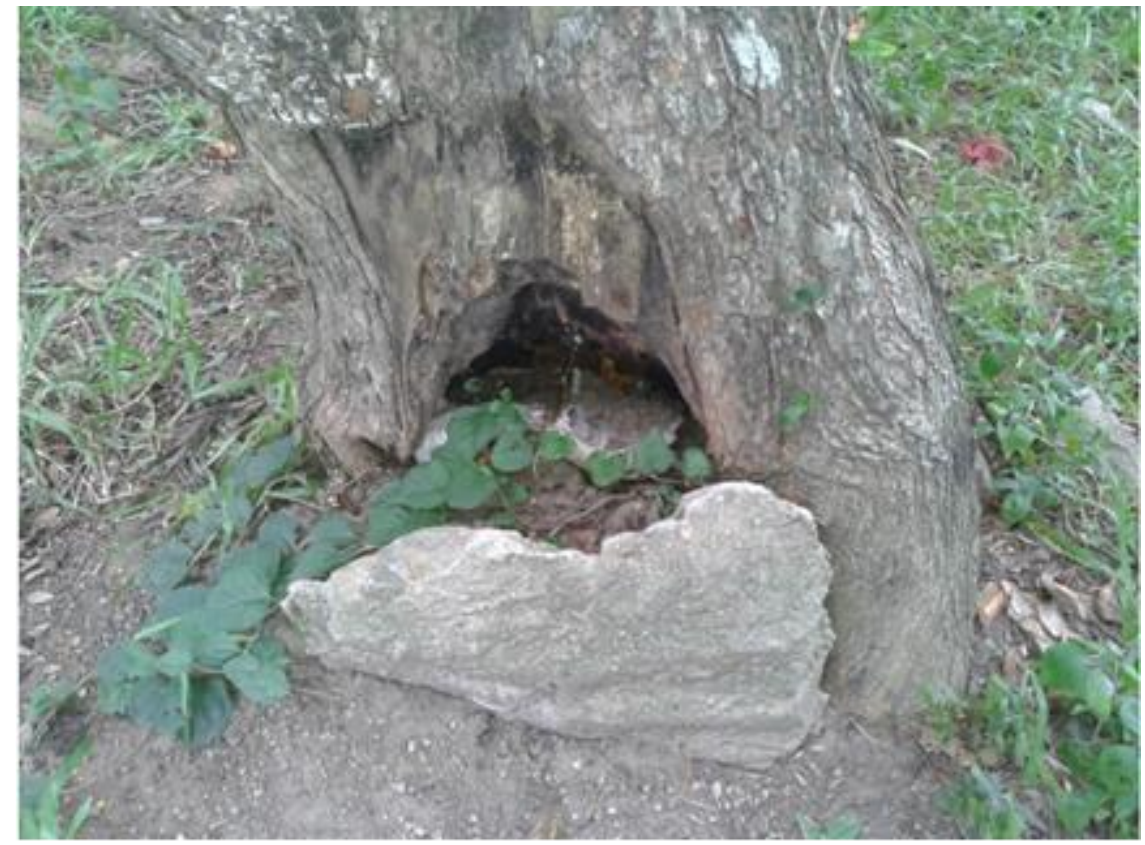

De acordo com Silva (2009), o que está marcado na paisagem, em geral, é resultado de grupos hegemônicos, grafias dos seus poderes de modificar a natureza.

O apego à forma material do espaço é um dos elementos fortemente constitutivos do eurocentrismo. A ênfase naquilo que é evidente, facilmente explicativo e verificável tem gerado a falsa impressão da neutralidade espacial, já que as formas não evidenciam, em si, seus interesses e relações de poder (SILVA, 2009).

Para Silva (2013), as experiências espaciais urbanas demostram que o espaço é vivenciado e interpretado de formas distintas pelos diferentes grupos sociais, quando indivíduos ou grupos manifestam suas vivências, suas percepções, através de um fazer político/cultural/religioso, que não corrobora com os discursos neoliberais de 
homogeneização do corpo e espaço. Conforme Santos (2011), o espaço geográfico não é apenas uma entidade objetiva, pode ser lido de forma intersubjetiva, assim a materialidade do espaço - (...) é dotada de significações específicas para cada indivíduo (subjetividade), mas que são também, em certa medida, compartilhadas por vários indivíduos (intersubjetividade) (SANTOS apud SOUZA 1995).

Figura 4 - Oferendas entregues junto a um conjunto de árvores no interior da Praça Darcy Azambuja (Acervo particular do autor).

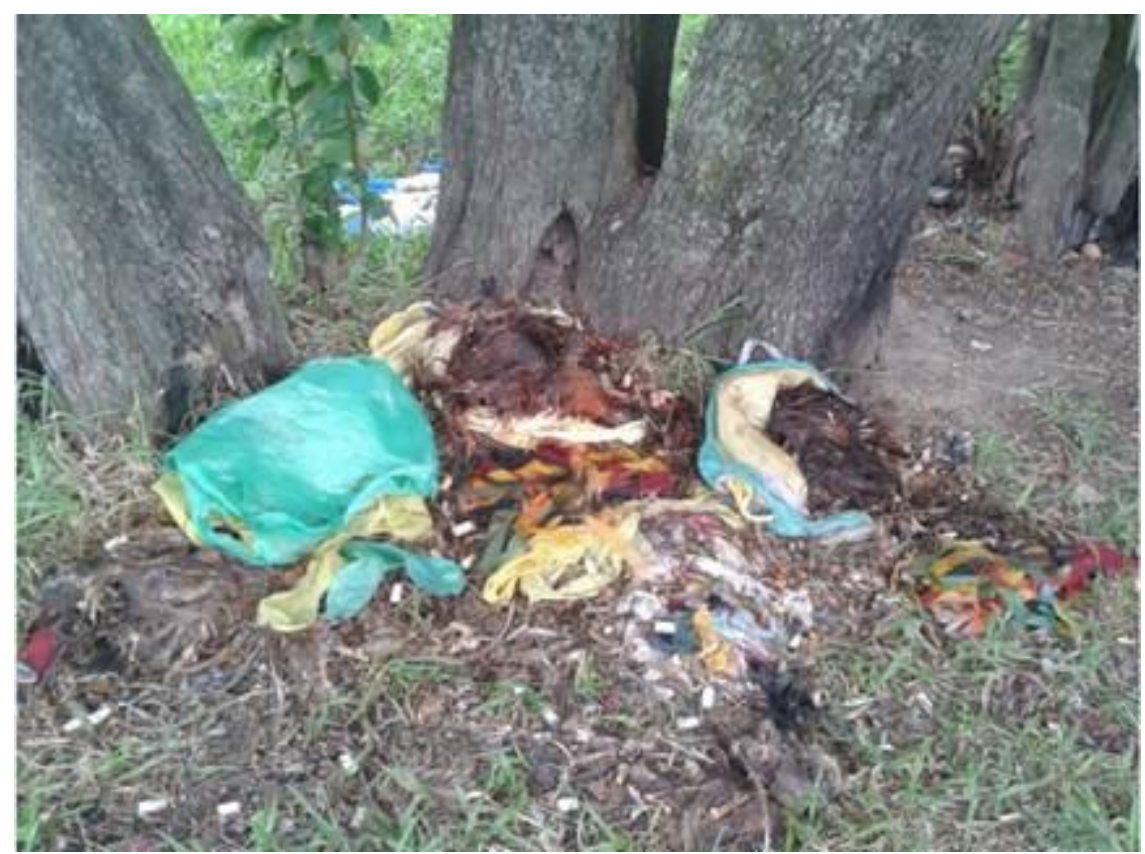

\subsection{Liberdade de culto: os orixás também comem}

A reflexão da sociedade é alimentada há milhares de anos pelas indagações cruciais sobre o sentido da vida e do mundo. Como resposta a esses questionamentos muitos homens baseiam suas vidas na religião. De acordo Firth (1974):

A religião é uma das principais forças que dirigem a atividade humana, tanto individual quanto socialmente [...]. Oferece um referente para a explicação de muitos acontecimentos da vida humana que parecem obscuros e exigem um significado. Podemos mesmo recorrer a ela para obter os princípios básicos de interpretação da história e da existência do próprio mundo (FIRTH, 1974).

Antes de se adentrar no aspecto conflituoso envolvendo as práticas religiosas realizadas nas Praças da Intercap, bairro Partenon, evidenciadas principalmente pelas oferendas e demandas formalizadas pelas religiões de matrizes africanas, torna-se 
necessário abordar de maneira mais profunda a questão que envolve as oferendas feitas aos orixás e que são deixadas na natureza, uma vez que é nos ambientes naturais que estas entidades se encontram e podem ser contatadas.

Conforme Costa (2008), os espaços da natureza também comem. Para os povos de santo, mar, rios, matas, estradas, pedreiras, cachoeiras, lagoas, e outros locais naturais que trazem a sinalização por monumentos ou elementos naturais, da marca e presença de um orixá também comem. Para a religiosidade africanista, é preciso alimentar a natureza, os deuses, os antepassados, que representam patronalmente os elementos ou são expressos nas atividades de transformação do mundo.

Os orixás são guerreiros, caçadores, ferreiros, reis, que desejam a garantia da harmonia entre hoje/vida e história/antepassado na temporalidade vigente na crença dos povos de santo. Como se houvesse uma espécie de boca geral, de grande boca do mundo, simbolizada pela natureza. E quem não come, não tem forca, não tem axé (COSTA, 2008).

O conceito de oferenda, portanto, se constitui no ato religioso de interação do fiel com seu guia, Orixá e forças da natureza. Para Lemos (2014), é de conhecimento público que algumas oferendas feitas por religiões de origem africana acabam por deixar resíduos de animais e "dejetos" em vias públicas. Ainda segundo este autor, a liberdade de culto não se constitui em uma carta branca para se fazer qualquer coisa em nome da religião. Se uma orientação religiosa faz com que locais públicos fiquem sujos de comida e animais mortos, isso é um fato que já não diz respeito somente aos integrantes dessa religião, é um caso de saúde e saneamento públicos, portanto envolve o direito de terceiros. A liberdade religiosa tem que ter limites também, que é justamente onde começam os direitos de outrem (LEMOS, 2014).

Para Farias (2012), a oferenda é a mais universal de todas as orações. Esteve e está presente, na maioria das religiões no mundo, ainda que de forma indireta, como acontece no ato de comunhão ou da páscoa do catolicismo brasileiro. Desse modo, não estamos abordando uma aberração de costumes, como fazem crer alguns seguimentos da sociedade brasileira (FARIAS, 2012). Quero acreditar antes que suas posturas preconceituosas são movidas, não somente pelo desconhecimento dos 
fundamentos desta religião tão rica em costumes, mas também porque desconhecem suas próprias práticas religiosas.

Seguindo pela linha legal, a liberdade religiosa é tida como uma liberdade secundária, derivada da liberdade primária de pensamento ou opinião. É o direito fundamental mais antigo da história do homem, tendo suas origens nas lutas religiosas posteriores à Reforma de Lutero.

No dizer de Soriano (2002), a liberdade religiosa é "uma espécie da qual a liberdade de pensamento é gênero". No conceito de Ferreira (1999), "a liberdade religiosa é o direito que tem o homem de adorar seu deus, de acordo com a sua crença e o seu culto".

A liberdade religiosa está inserida entre direitos da liberdade, os chamados direitos fundamentais de primeira dimensão e, ainda, na categoria das liberdades públicas. Greco-Filho (1989) explica que "a liberdade se resume sempre em um poder de agir e de não agir; ela é 'pública' na medida do fato de não estar submetida aos imperativos jurídicos fixados pelo Estado".

Nesta linha, a Declaração Universal dos Direitos Humanos, de 1948, garante o direito, que constitui o tema central desta pesquisa, à liberdade religiosa. Atentaremos para o artigo 18 da Declaração que versa em específico sobre o assunto:

Artigo 18

Todo o homem tem direito à liberdade de pensamento, consciência e religião; este direito inclui a liberdade de mudar de religião ou crença e a liberdade de manifestar essa religião ou crença, pelo ensino, pela prática, pelo culto e pela observância, isolada ou coletivamente, em público ou em particular.(grifos nossos)

O Pacto San Jose da Costa Rica, assinado em 1969 e ratificado pelo Brasil em 25 de setembro, merece destaque dentre outros que dispõem sobre a liberdade religiosa. A forte expressão da Convenção Americana de Direitos Humanos, como também é conhecido o pacto, se revela na medida em que amplia o disposto na Constituição Federal ao pormenorizar em que consiste a liberdade de crença e ao incluir a liberdade de divulgar a religião e de educar os filhos na religião que segue.

No que tange ao à liberdade de culto, dispõe o artigo 12, in verbis: 
Liberdade de Consciência e de Religião

1. Toda pessoa tem direito à liberdade de consciência e de religião. Esse direito implica a liberdade de conservar sua religião ou suas crenças, ou de mudar de religião ou de crenças, bem como a liberdade de professar e divulgar sua religião ou suas crenças, individual ou coletivamente, tanto em público como em privado.

$[\ldots]$

3. A liberdade de manifestar a própria religião e as próprias crenças está sujeita unicamente às limitações prescritas pela lei e que sejam necessárias para proteger a segurança, a ordem, a saúde ou a moral públicas ou os direitos e as liberdades das demais pessoas.

Este tratado, ainda, possui especial importância no ordenamento jurídico pátrio no que se refere ao tema aqui abordado por estabelecer alguns aspectos em que a liberdade de manifestação religiosa pode ser restringida. Ademais, menciona o direito de divulgar a crença religiosa e o proselitismo religioso, aqui entendido como a possibilidade de alguém, por manifestação de suas ideias, converter terceiros à sua religião.

Assim estabelece a Constituição Federal, de 1988,

Art. $5^{\circ}$ Todos são iguais perante a lei, sem distinção de qualquer natureza, garantindo-se aos brasileiros e aos estrangeiros residentes no País a inviolabilidade do direito à vida, à liberdade, à igualdade, à segurança e à propriedade, nos termos seguintes:

$[\ldots]$

$\mathrm{VI}$ - é inviolável a liberdade de consciência e de crença, sendo assegurado o livre exercício dos cultos religiosos e garantida, na forma da lei, a proteção aos locais de culto e a suas liturgias; (grifos nossos)

A liberdade de culto garante aos "crentes de qualquer religião honrar a divindade como melhor lhes parecer, celebrando as cerimônias exigidas pelos rituais" (FERREIRA-FILHO, 1999). Distingue-se da liberdade de crença por envolver a manifestação da religião.

A proteção ao culto também se verifica no artigo 208 do Código Penal, que estabelece o crime de ultraje a culto e impedimento ou perturbação de ato a ele relativo no artigo supramencionado, de modo a dar eficácia ao disposto no artigo $5^{\circ}$, inciso VI, da Constituição Federal, in verbis: 
Art. 208. Escarnecer de alguém publicamente, por motivo de crença ou função religiosa; impedir ou perturbar cerimônia ou prática de culto religioso; vilipendiar publicamente ato ou objeto de culto religioso:

Pena - detenção, de um mês a um ano, ou multa.

Parágrafo único. Se há emprego de violência, a pena é aumentada de um terço, sem prejuízo da correspondente à violência.

\subsection{A problemática ambiental}

Quando os praticantes sentem a necessidade de deixar a oferenda junto a natureza, podem ocorrer alguns problemas ambientais, tais como a queima de troncos por velas (figs. 2 e 3), consumo de alimentos por animais nativos (ou urbanizados) e urbanos (figs. 5 e 6), poluição do solo e da água.

A fauna urbanizada, apesar de sua notória adaptação ao ambiente urbano, ainda assim pode se revelar muito sensível as alterações nos seus padrões de vida, por isso não deve ser oportunizada a disposição de qualquer origem, sejam resíduos de oferendas ou outros resíduos orgânicos de origens diversas (figs. 5 e 6).

Figura 5 - Exemplar de Coragyps atratus (Bechstein, 1793) se alimentando em oferenda na Praça Darcy Azambuja (Acervo particular do autor).

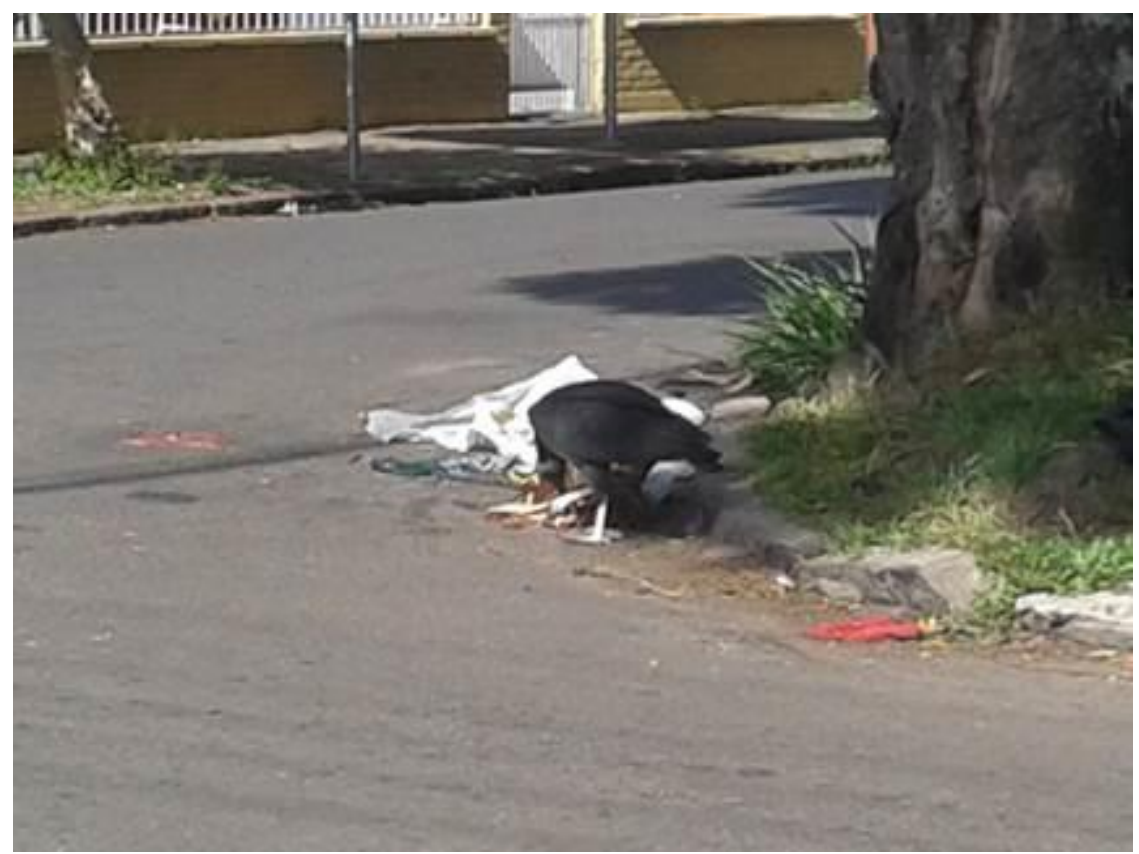


Figura 6 - Cão abandonado se alimentando em oferenda na Praça Darcy Azambuja (Acervo particular do autor).

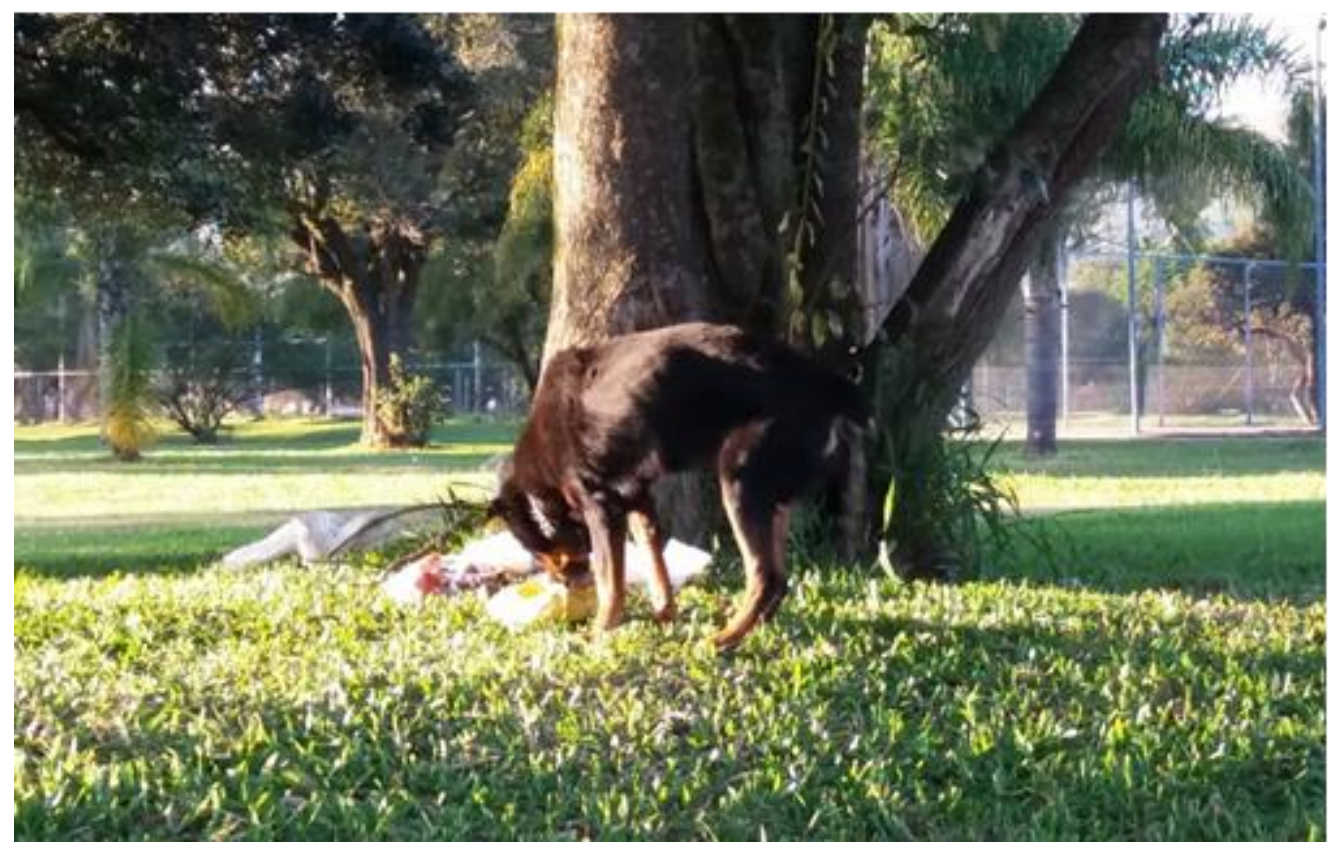

Oferendas, conforme se observa nas figuras 2 à 6 , se constituem em dois componentes, matéria orgânica e constituintes inorgânicos - especialmente plásticos e parafina das velas. Sua excessiva deposição, ocasiona uma forma de poluição visual nas praças, agredindo a paisagem na qual se encontra inserida.

A poluição visual ocorrida na degradação do ambiente "é fruto da violação estética de um padrão paisagístico médio a ser aferido em cada caso, seja afetando uma paisagem naturalmente bela, ou portadora de outro predicado relevante, ou alterando uma paisagem urbana de maneira desarmônica e agressiva" (CASTANHEIRO, 2009).

O direito do ambiente é orientado por três princípios fundamentais: o princípio da precaução, o da cooperação ou da participação e o princípio do poluidor pagador. Mas, a saúde e a qualidade ambientais guardam relação diretamente proporcional ao grau de envolvimento das pessoas e dos Poderes constituídos frente às questões atinentes a tudo que envolve o patrimônio ambiental e, por conseguinte, a dignidade da pessoa humana.

A Lei Federal $N^{\circ} 6.938 / 1981$ adotou o princípio do poluidor pagador, ao apontar como uma das finalidades da Política Nacional do Meio Ambiente "a 
imposição ao usuário, da contribuição pela utilização dos recursos ambientais com fins econômicos e da imposição ao poluidor e ao predador da obrigação de recuperar e/ou indenizar os danos causados".

O princípio do poluidor-pagador pode ser entendido como sendo um instrumento econômico e também ambiental, que exige do poluidor, uma vez identificado, suportar os custos das medidas preventivas e/ou das medidas cabíveis para, senão a eliminação pelo menos a neutralização dos danos ambientais.

É oportuno detalhar que este princípio não permite a poluição e nem pagar para poluir. Pelo contrário, procura assegurar a reparação econômica de um dano ambiental quando não for possível evitar o dano ao meio ambiente, através das medidas de precaução. Desta forma, o princípio do poluidor-pagador não se reduz à finalidade de somente compensar o dano ao meio ambiente, deve também englobar os custos necessários para a precaução e prevenção dos danos, assim como sua adequada repressão.

Coadunando com esta perspectiva, Barde e Girelli apud Colombo (2004), afirmam que "o princípio do poluidor-pagador não é um princípio de responsabilidade civil: vimos que a identificação do responsável não constitui de modo nenhum o ponto central de uma política ambiental. Cabe aos poderes públicos determinar o nível de intervenção mais eficaz".

Ainda nesta linha e considerando o particular de se tratarem de Praças em Porto Alegre, tem-se a Lei Federal N9.605/1998, segundo a qual:

Art. 38-A. Destruir ou danificar vegetação primária ou secundária, em estágio avançado ou médio de regeneração, do Bioma Mata Atlântica, ou utilizá-la com infringência das normas de proteção:

Pena - detenção, de 1 (um) a 3 (três) anos, ou multa, ou ambas as penas cumulativamente.

Parágrafo único. Se o crime for culposo, a pena será reduzida à metade.

$[\ldots]$

Art. 49. Destruir, danificar, lesar ou maltratar, por qualquer modo ou meio, plantas de ornamentação de logradouros públicos ou em propriedade privada alheia: 
Pena - detenção, de três meses a um ano, ou multa, ou ambas as penas cumulativamente.

Parágrafo único. No crime culposo, a pena é de um a seis meses, ou multa.

$[\ldots]$

Art. 54. Causar poluição de qualquer natureza em níveis tais que resultem ou possam resultar em danos à saúde humana, ou que provoquem a mortandade de animais ou a destruição significativa da flora:

Pena - reclusão, de um a quatro anos, e multa.

$[\ldots]$

(grifos nossos)

Hierarquicamente, tem-se então a Lei Complementar Municipal de $N^{\circ} 757$, de 14 de janeiro de 2015, estabelecendo:

Art. 46. Para os fins desta Lei Complementar, ficam estabelecidas penalidades para as seguintes condutas:

I - podar ou danificar vegetação nativa, sem autorização do órgão ambiental competente, multa de 150 (cento e cinquenta) a 50.000 (cinquenta mil) UFMs;

$[\ldots]$

III - podar ou danificar vegetação exótica, sem autorização do órgão ambiental competente, multa de 70 (setenta) a 2.000 (duas mil) UFMs;

(grifos nossos)

Em paralelo, não menos importante, tem-se a Lei Complementar Municipal de N728, de 08 de janeiro de 2014, que já estabelecia:

Art. $3^{\circ}$ Para fins desta Lei Complementar, consideram-se:

I - resíduos sólidos de limpeza urbana os originários da varrição e demais serviços de limpeza executados nos logradouros públicos;

$[\ldots]$

Art. 44. São atos lesivos à limpeza urbana:

I - depositar, lançar ou atirar, nos passeios ou nos logradouros públicos, papéis, invólucros, embalagens ou assemelhados que causem danos à conservação da limpeza urbana, constituindo infração leve, punível conforme o art. 52, inc. I, desta Lei Complementar;

$[\ldots]$

III - depositar, lançar ou atirar, em quaisquer áreas públicas ou terrenos, edificados ou não, de propriedade pública ou privada, resíduos sólidos de 
qualquer natureza em volume: a) de até 100 (cem) litros, constituindo infração grave, punível conforme o art. 52, inc. III, desta Lei Complementar;

$[\ldots]$

VII - depositar, lançar ou atirar em riachos, canais, arroios, córregos, lagos, lagoas e rios, ou às suas margens, resíduos de qualquer natureza que causem prejuízo à limpeza ou ao meio ambiente, constituindo infração gravíssima, punível conforme o art. 52, inc. IV, desta Lei Complementar;

$[\ldots]$

XI - depositar em passeios, vias ou logradouros públicos, riachos, canais, arroios, córregos, lagos, lagoas e rios ou em suas margens animais mortos ou partes deles, constituindo infração média, punível conforme o art. 52, inc. II, desta Lei Complementar.

$[\ldots]$

\$3० Excetua-se ao disposto no inc. XI do caput deste artigo a utilização de animais em cultos e liturgias de religiões de matriz africana e da umbanda.

(grifos nossos)

\section{CONSIDERAÇÕES FINAIS}

A liberdade religiosa é um direito fundamental. Os elementos essenciais foram incorporados na declaração universal dos direitos do homem, assim, o direito à liberdade religiosa inclui o direito de se ter uma religião, de se mudar de religião ou crença e o direito de se manifestar a religião em público ou em particular. Portanto, os direitos são no Brasil, um direito do cidadão.

A compreensão do comportamento do sujeito religioso em relação ao espaço dá-se através da categoria espaço sagrado, sendo possível entender as dinâmicas das espacialidades religiosas, visto que estas fornecem elementos da cosmovisão religiosa, bem como as práticas cotidianas dos fiéis.

Porém, as diferenças corporais devem ser percebidas em um espaço, por se entender que o mesmo é concebido através das relações sociais projetadas nele. As relações são relacionais, assim como é o espaço e que se tenciona com outros espaços. $E$, neste sentido, o direito à liberdade religiosa está apropriadamente amparado pela Constituição brasileira e por tratados internacionais. A questão, entretanto, como bem disse Norberto Bobbio, não consiste em fundamentar e, sim, 
em proteger. $E$, neste sentido, a liberdade religiosa deve ser exercida com respeito aos demais direitos assegurados, até a nível constitucional, ao cidadão.

É fato, por conseguinte e do ponto de vista ético e moral, que o estabelecimento de uma crença religiosa corroborou para que o homem evoluísse, pois ditava quais atos deveriam ser seguidos e os que não deveriam ser praticados, transportando, então, o homem primitivo ao homem moderno - que, em comparação ao primeiro, é dotado de uma consciência mais voltada a ética (embora ter consciência ética não significa ser ético).

Quando se realiza a análise dos valores dos lugares para os grupos religiosos, particularmente os afrobrasileiros percebe-se que estes constituem um valor de relação afetiva estabelecida naquele espaço, já para outras denominações religiosas desvalorizam o valor do significado fenomenológico que este lugar simbólico tem para o primeiro grupo.

O valor do lugar é expresso pela referência para um sujeito ou um grupo, pois lá tiveram experiências significativas pela religiosidade que compartilham. Quando há divergências sobre o valor de uso destes lugares, ou seja, confrontos de interpretação, o conceito de lugar e/ou mundo vivido, se torna insuficiente.

O ponto nevrálgico do conflito olhando-se sob a ótica da escola conservacionista brasileira, consiste no deixar oferendas e o utiliza o fogo, duas práticas proibidas pela lei de crimes ambientais, se se for pensada a oferenda como lixo, como resíduo. E do ponto de vista da conservação, oferenda é vista como lixo, e, portanto, instrumento de degradação.

Para os devotos é presente para deidade, e acaba se convertendo em instrumento de degradação pela omissão dos órgãos públicos em estabelecer uma política de coleta regular de resíduos nos ambientes utilizados pelas religiões afrobrasileiras. Acaba que a religião passa a ser acusada de poluidora, e seus adeptos são transformados em agentes de degradação da natureza, quando não e isso que ocorre.

Apesar disto, as normas protetoras do direito à liberdade religiosa têm eficácia absoluta, não podendo ser restringidas, através de Emendas ou com a elaboração de leis infraconstitucionais. Convém, inclusive, recordar que a Lei Federal N 10.639/2003 
alterou a LDBEN (Lei Federal N 9.394/1996) para incluir no currículo oficial de ensino a obrigatoriedade das instituições públicas e privadas de ter conteúdos programáticos sobre a História e Cultura Afro-Brasileira e Africana.

Convém estabelecer que é imprescindível que as pessoas se conscientizem quanto à necessidade de cumprimento de seu dever constitucional, qual seja, dentre outros, o de zelar pela saúde ambiental, posto que, em agindo com respeito ao ambiente, receberão a contrapartida lógica, qual seja a oportunidade de gozo do constitucional e fundamental direito ao ambiente equilibrado - requisito indispensável da dignidade da pessoa humana (fundamento de validade de todos os direitos humanos tidos como fundamentais). Essa conscientização passa, primordialmente, por uma reeducação ambiental que permita às pessoas, imbuídas do senso de solidariedade para com as gerações futuras e para com as demais espécies de vida, assimilarem a ideia de que a saúde do ambiental é fundamento existencial do princípio da dignidade humana.

No direito, não existe um único tema que não comporte discussão, ou que esteja completamente exaurido; sendo que a proteção ambiental, enquanto instrumento indispensável para o alcance e preservação da dignidade da pessoa humana, deve estar alicerçada no princípio da solidariedade. Assim, em que pese a liberdade religiosa, o operador do direito deve ser cauteloso, para evitar juízos precipitados. Cabe, então, a este operador, conhecer não apenas o ordenamento jurídico, mas toda a realidade social pertinente à matéria em tela, daí a necessidade de se recorrer a outras áreas do conhecimento humano, como, a história, a filosofia, a biologia e a teologia.

Admitida essa visão doutrinária, não haveria colisão de direitos, prevaleceria a preservação da cultura.

\section{REFERÊNCIAS}

BOBBIO, N. A era dos direitos. 11ed., Rio de Janeiro: Campus, 1992.

BRASIL. Constituição da República Federativa do Brasil, de 05 de outubro de 1988. Disponível on line em: 
http://www.planalto.gov.br/ccivil_03/constituicao/constituicaocompilado.htm. Acesso em: 14 mar. 2017.

BRASIL. Decreto Federal $N^{\circ}$ 678, de 06 de novembro de 1992. Promulga a Convenção Americana sobre Direitos Humanos (Pacto de São José da Costa Rica), de 22 nov. 1969.

BRASIL. Lei Federal N².848, de 07 de dezembro de 1940. Código Penal.

BRASIL. Lei Federal $\mathbf{N}^{\circ} \mathbf{6 . 9 3 8}$, de 31 de agosto de 1981. Dispõe sobre a Política Nacional do Meio Ambiente, seus fins e mecanismos de formulação e aplicação, e dá outras providências.

BRASIL. Lei Federal $\mathbf{N}^{\circ}$ 9.394, de 20 de dezembro de 1996. Estabelece as diretrizes e bases da educação nacional.

BRASIL. Lei Federal $\mathbf{N}^{\circ}$ 9.605, de 12 de fevereiro de 1998. Dispõe sobre as sanções penais e administrativas derivadas de condutas e atividades lesivas ao meio ambiente, e dá outras providências.

BRASIL. Lei Federal N 10.639 de 09 de janeiro de 2003. Altera a Lei no 9.394, de 20 dez. 1996, que estabelece as diretrizes e bases da educação nacional, para incluir no currículo oficial da Rede de Ensino a obrigatoriedade da temática "História e Cultura Afro-Brasileira", e dá outras providências.

COLOMBO, S. Aspectos conceituais do princípio do poluidor-pagador. Rev. eletrônica Mestr. Educ. Ambient., Rio Grande, v. 13, p. 16-51. 2004. Disponível on line em: https://periodicos.furg.br/remea/article/viewFile/2720/1555 Acesso em: 03 out. 2018.

CASTANHEIRO, I. C. A Poluição Visual: Formas de Enfrentamento pelas Cidades. Revista Internacional de Direito e Cidadania, n.4, p.63-78. 2009.

COSTA, L. M. da. A Floresta Sagrada da Tijuca: Estudo de caso de conflito envolvendo o uso público religioso de Parque Nacional. 2008. 409p. Dissertação (Mestrado em Psicossociologia de Comunidades e Ecologia Social) - Universidade Federal do Rio de Janeiro - UFRJ, Instituto de Psicologia - Programa de Estudos Interdisciplinares de Comunidades e Ecologia Social - EICOS, Rio de Janeiro.

DE-ANGEliS, B. L. D; ANGEliS-NetO, G. de; BARROS, G. D. A.; BARROS, R. D. A. Praças: história, usos e funções. Maringá: EDUEM, 2005.

FARIAS, I. V. da S. O ritual de oferenda na umbanda e o culto a natureza: processos de significação. 2012. 128p. Dissertação (Mestrado em Antropologia) - Universidade Federal de Sergipe, Núcleo de Pós-Graduação e Mestrado em Antropologia, São Cristóvão.

FERREIRA, P. Curso de Direito Constitucional. 10ed. rev. e atual. São Paulo: Saraiva, 1999.

FIRTH, R. Elementos de Organização Social. Rio de Janeiro: Zahar Editores, 1974.

GIL-FILHO, S. F. Espaço Sagrado: Estudos em Geografia da Religião. Curitiba: IBPEX, 2008.

GRECO-FILHO, V. Tutela constitucional das liberdades. São Paulo: Saraiva, 1989. 
LEMOS, P. Cemitérios Proíbem Cultos Afro no Rio. Blog pessoal. 05 dez. 2014. Disponível on line em: https://ateuedai.com/2014/12/05/cemiterios-proibem-cultos-afro-norio/. Acesso em: 16 mar. 2017.

LOUREIRO, C. F.; AZAZIEL, M.; FRANCA, N. Educação ambiental e conselho em unidade de conservação: aspectos teóricos e metodológicos. Rio de Janeiro: IBASE: Instituto Terra Azul: Parque Nacional da Tijuca, 2007. 88p. Disponível on line em: http://ibase.br/userimages/liv_ibase_pnt.pdf. Acesso em: 05 fev. 2017.

OEA. Convenção Americana sobre Direitos Humanos, de 22 de novembro de 1969. Disponível on

line

em: https://www.cidh.oas.org/basicos/portugues/c.convencao_americana.htm. Acesso em: 14 mar. 2017.

ONU. Declaração Universal dos Direitos Humanos. Proclamada em Paris, em 10 de dezembro de 1948. Disponível on line em: http://www.dhnet.org.br/direitos/deconu/textos/integra.htm Acesso em: 14 mar. 2017.

PORTO ALEGRE. Lei Complementar Municipal N 728, de 08 de janeiro de 2014. Institui

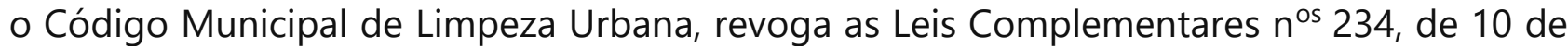
outubro de 1990, 274, de 25 de março de 1992, 376, de 3 de junho de 1996, 377, 3 jun. 1996, 591, de 23 de abril de 2008, e 602, de 24 nov. 2008, e dá outras providências.

PORTO ALEGRE. Lei Complementar Municipal № 757, de 14 de janeiro de 2015. Estabelece regras para a supressão, o transplante ou a poda de espécimes vegetais no Município de Porto Alegre, revoga os Decretos $n^{\text {os }} 10.237$, de 11 de março de 1992, 10.258, de 3 de abril de 1992, 15.418, de 20 de dezembro de 2006, 17.232, de 26 de agosto de 2011, 18.083, de 21 nov. 2012, e 18.305, de 28 de mai. 2013, e dá outras providências.

SANTOS, C. Geografia e Fenomenologia: Algumas aproximações a partir da Geografia Humanista e da Geografia das Representações. Diálogos, n. 5, p. 72-83, 2011. Disponível em: http://www.orfeuspam.com.br/periodicos_jl/dialogos/dialogos_5/clelio_santos.pdf. Acesso em: 08 Out. 2018.

SILVA, J. M. Geografias Subversivas: discursos sobre espaço, gênero e sexualidades. Ponta Grossa: Todapalavra, 2009.

SILVA, R. C. da. Conflitos religiosos e espaço urbano contemporâneo: Cruzamentos dos fenômenos de dispersão espacial dos sistemas de significações religiosas de neopentecostais e religiões afro-brasileiras no Rio de Janeiro. 2013. 181p. Dissertação (Mestrado em Geografia) - Universidade Federal de Santa - UFSM - Programa de Pósgraduação em Geografia e Geociências, Santa Maria.

SOUZA, M. J. L. de. O território: sobre espaço e poder, autonomia e desenvolvimento. In: CASTRO, Iná Elias de. CORRÊA, R. L. et. al. Geografia: conceitos e temas. Rio de Janeiro: Bertrand Brasil, 1995. p. 77-116.

SORIANO, A. G. Liberdade religiosa no direito constitucional e internacional. São Paulo: Juarez de Oliveira, 2002 